International Journal of Pharmaceutics \& Pharmacology

EDW SER

Available Online: http://ijpp.edwiserinternational.com

\title{
Phytochemical Profile of Trigonella foenum graecum Linn.
}

Vasant B Kadam*

Department of Botany and Research Centre, K.T.H.M.College, Nashik, Maharashtra, India

Article info

Received 24 May 2018

Revised 25 June 2018

Published 29 June 2018

*Corresponding author: Vasant B

Kadam, Department of Botany and

Research Centre, K.T.H.M.

College, Nashik-2, India, E-mail:

drvbkadam@yahoo.com

\begin{abstract}
The seasonal variation of protein, amino acids and alkaloids has been investigated in leaves, stem, roots and seeds of Trigonella foenum graecum. The leaves of Trigonella foenum graecum showed high level of protein content during summer season $(5.131 \mathrm{mg} / \mathrm{g}$ dry wt.) than monsoon $(4.563$ $\mathrm{mg} / \mathrm{g}$ dry wt.) and winter $(4.637 \mathrm{mg} / \mathrm{g} d r y \mathrm{wt}$.) season. Comparative account of amino acid content of leaves of Trigonella foenum graecum showed higher level in summer season $(0.914 \mathrm{mg} / \mathrm{g}$ dry wt.) and lowest amount of amino acid content in the leaves during monsoon $(0.832 \mathrm{mg} / \mathrm{g}$ dry/wt.) season. The leaves of Trigonella foenum graecum showed high level of alkaloid content in seeds $(4.167 \mathrm{mg} / \mathrm{g} / \mathrm{dry} \mathrm{wt}$.) and lower alkaloid content in root (range 1.006 to $1.231 \mathrm{mg} / \mathrm{g}$ dry $\mathrm{wt}$.).
\end{abstract}

Keywords: Protein; Alkaloid; Amino acids; Trigonella foenum-graecum

\section{Introduction}

Since the ancient times, nature has been a huge source of medicinal agents. All over the world, plants have served as the richest source of raw materials for traditional as well as modern medicine [1,2]. The medicinal value of plants is mainly due to the presence of some chemical substances known as photochemical. They are basically plant metabolites, are synthesized in all parts of plant body itself and have some definite physiological action on animals $[3,4]$. In view of the increasing demand for protein and energy to support the growing world population, researchers have directed their efforts at exploring new and nonconventional sources of food that grow in the different regions of the world. Nature has bestowed upon us a very rich botanical wealth and a large number of diverse types of plants grow wild in different parts of our country. The important constituents of diet are carbohydrates, fats, proteins, vitamins, minerals and water [5]. Every constituent plays an important role and deficiency of any one constituent may lead to abnormal developments in the body. Plants are the rich source of all the elements essential for human beings.
Trigonella foenum graecum is commonly known as fenugreek (English). Trigonella foenum-graecum is reported to contain several active chemical constituents such as alkaloids, saponins, steroids, tannins, flavonoids, amino acids and trigonilline. The plant has been scientifically used for the treatment of wounds, inflammation, gastrointestinal ailments, as cholesterol lowering agent, diabetes, bronchitis, inflammation, chronic cough, liver disorder and as an anti-fertility agent. Trigonella foenum-graecum is one such plant that has been extensively used as a source of antidiabetic compounds from its seeds, leaves and extracts in different model systems [6-8]. Fenugreek is traditionally used in India, especially in the Ayurveda and Unani systems [7-9]. The seeds possess antidiabetic potentials [10].

\section{Materials and Methods}

The plant material of Trigonella foenum-graecum were collected from our botanical garden, during different season's viz. summer, monsoon and winter continuous 
two years for estimation of protein, amino acids and alkaloids.

The protein was quantitatively estimated by Lowry et.al [11]. $1 \mathrm{gm}$ plant material was homogenized with $10 \mathrm{ml}$ $80 \%$ ethanol. The extract was centrifuged at $5000 \mathrm{rpm}$ for $5 \mathrm{~min}$ and the supernatant was discarded. 5\% of 10 $\mathrm{ml}$ Trichloro Acetic Acid (TCA) or Per Chloric Acid (PCA) was add to residue and incubated at $80^{\circ} \mathrm{C}$ for 20 minutes. The pallets were centrifuged, and the supernatant was discarded. Residue was washed with 10 $\mathrm{ml}$ distilled water and again centrifuged. The supernatant was discarded. $2 \% 10 \mathrm{ml} \mathrm{Na}_{2} \mathrm{CO}_{3}$ in $0.1 \mathrm{~N}$ $\mathrm{NaOH}$ was add to the residue and incubated for an hour at $30^{\circ} \mathrm{C}$. Again, centrifuged and residue was discarded. The final volume of supernatant was measured, and it was used as a sample for protein. $1 \mathrm{ml}$ of aliquot of sample was taken and $5 \mathrm{ml}$ reagent $\mathrm{C}$ was added to it and mixed thoroughly. The sample was incubated for 10 minutes and $1 \mathrm{ml}$ of reagent $\mathrm{D}$ was added to it. The colour intensity was read at $660 \mathrm{~nm}$ using spectrophotometer. The protein concentration of an unknown sample was calculated using standard graph.

The estimation of total amino acid was adapted by Krishnamurthy et. al. method [12]. $500 \mathrm{mg}$ plant material was grounded in mortar and pestle with few drops of cold $80 \%$ ethanol. Then $2.5 \mathrm{ml}$ of distilled water and $10 \mathrm{ml}$ of boiling $80 \%$ ethanol were added to it. The extract was centrifuged for 15 minutes at 10,000 rpm. Residue was discarded. The supernatant was collected, and total volume was made $15 \mathrm{ml}$ with distilled water. $1 \mathrm{ml}$ of sample was taken in a test tube and $3 \mathrm{ml}$ alcoholic ninhydrin was added to it. Test tube was kept at $60^{\circ} \mathrm{C}$ for 20 minutes. The test tubes were cooled, and $1 \mathrm{ml} 50 \%$ ethanol was added. Read at 420 $\mathrm{nm}$ in spectrophotometer. Glycine was used as standard.

Quantitative estimation of alkaloids was carried out by the method of Sairam and Khanna [13]. Each sample was ground to fine powder. To each one-gram powder $0.75 \mathrm{ml} 25 \%$ ammonium hydroxide, $1 \mathrm{ml} \mathrm{95 \%} \mathrm{ethyl}$ alcohol and $2 \mathrm{ml}$ ethyl ether were added. The material was allowed to macerate for 12 hours and dried. The dried material was extracted with chloroform for 24 hours in a soxhlet apparatus and the extract obtained was evaporated to dryness, and the residue was mixed with $2.5 \mathrm{ml}$ of 0.1 Methanol (90\%) HCL. The extract thus obtained was centrifuged to take supernatant and discard pellet. The solution was evaporated, and the total alkaloids were weight after drying at $100^{\circ} \mathrm{C}$.

\section{Results and Discussion}

The protein content of leaves was higher $(5.131 \mathrm{mg} / \mathrm{g}$ dry wt.) in summer over than winter $(4.637 \mathrm{mg} / \mathrm{g}$ dry wt.) and monsoon $(4.563 \mathrm{mg} / \mathrm{g}$ dry wt.). The range of protein content of stem was from $(3.013 \mathrm{mg} / \mathrm{g}$ dry wt. to $3.576 \mathrm{mg} / \mathrm{g}$ dry wt.). The range of protein content in root was from $(1.176 \mathrm{mg} / \mathrm{g}$ dry wt. to $1.387 \mathrm{mg} / \mathrm{g}$ dry wt.) and show higher in summer. The protein content of root was very low in all season. The protein content of seeds was higher (23.220 mg/g dry wt.) as compared to leaves, stem and roots of all seasons. The protein content showed increasing order of root $<$ stem $<$ leaves $<$ seeds. (Table 1 and Figure 1).

The amino acids content of leaves was $(0.914 \mathrm{mg} / \mathrm{g}$ dry wt.) in summer, (0.869 $\mathrm{mg} / \mathrm{g}$ dry wt.) in winter and $(0.832 \mathrm{mg} / \mathrm{g}$ dry wt.) in monsoon. Higher being observed during summer i.e. (0.914 $\mathrm{mg} / \mathrm{g}$ dry wt.). The range of amino acids content in stem were $(0.518 \mathrm{mg} / \mathrm{g}$ dry wt. to $0.610 \mathrm{mg} / \mathrm{g}$ dry wt.). Maximum concentration of amino acids was noted during summer $(0.610 \mathrm{mg} / \mathrm{g}$ dry wt.). The range of amino acid content of root was low from $(0.019 \mathrm{mg} / \mathrm{g}$ dry wt. to $0.025 \mathrm{mg} / \mathrm{g}$ dry wt.). The amino acids content of seeds was higher (9.434 $\mathrm{mg} / \mathrm{g}$ dry wt.) as compared to leaves, stem and roots of all seasons. Generally, the concentration of amino acids was found to be in increasing order of root<stem< leaves $<$ seeds. (Table 1 and Figure 1).

The alkaloids content of leaves was ranging from $(2.458$ $\mathrm{mg} / \mathrm{gm}$ dry wt. to $3.100 \mathrm{mg} / \mathrm{gm}$ dry wt.) and attained its peak concentration $(3.100 \mathrm{mg} / \mathrm{gm}$ dry wt.) during summer season. The range of alkaloid content was from ( $1.872 \mathrm{mg} / \mathrm{gm}$ dry wt. to $2.270 \mathrm{mg} / \mathrm{gm}$ dry wt.) in stem and from $(1.006 \mathrm{mg} / \mathrm{gm}$ dry wt. to $1.231 \mathrm{mg} / \mathrm{gm}$ dry wt.) in root during the three seasons tested. Highest concentration observed in summer season i.e. (1.231 $\mathrm{mg} / \mathrm{gm}$ dry wt. and $1.093 \mathrm{mg} / \mathrm{gm}$ dry wt.) in winter. Seeds content highest ( $4.167 \mathrm{mg} / \mathrm{gm}$ dry wt.) amount of alkaloid content compared to leaves, stem and roots of all seasons (Table 1 and Figure 1).

Table 1: Seasonal variations of protein, amino acids and alkaloids of various parts of Trigonella foenum-graecum.

\begin{tabular}{|l|l|l|l|l|}
\hline Plant parts & Seasons & $\begin{array}{l}\text { Protein } \\
\text { mg/gm.dry wt. }\end{array}$ & $\begin{array}{l}\text { Amino acids } \\
\text { mg/gm.dry wt. }\end{array}$ & $\begin{array}{l}\text { Alkaloids } \\
\text { mg/gm.dry wt. }\end{array}$ \\
\hline \multirow{2}{*}{ Leaves } & Summer & 5.131 & 0.914 & 3.100 \\
\cline { 2 - 5 } & Monsoon & 4.563 & 0.832 & 2.458 \\
\hline
\end{tabular}


Citation: Kadam VB. Phytochemical Profile of Trigonella foenum graecum Linn. Int J Pharm Pharmacol 2018; 2: 130. doi: 10.31531/2581-3080.1000130

\begin{tabular}{|l|l|l|l|l|}
\hline & Winter & 4.637 & 0.869 & 2.742 \\
\hline \multirow{4}{*}{ Stem } & Summer & 3.576 & 0.610 & 2.270 \\
\cline { 2 - 5 } & Monsoon & 3.013 & 0.518 & 1.872 \\
\cline { 2 - 5 } & Winter & 3.241 & 0.561 & 2.041 \\
\hline \multirow{3}{*}{ Roots } & Summer & 1.387 & 0.025 & 1.231 \\
\cline { 2 - 5 } & Monsoon & 1.176 & 0.019 & 1.006 \\
\cline { 2 - 5 } & Winter & 1.262 & 0.021 & 1.093 \\
\hline \multirow{2}{*}{ Seeds } & -- & 23.220 & 9.434 & 4.167 \\
\hline
\end{tabular}

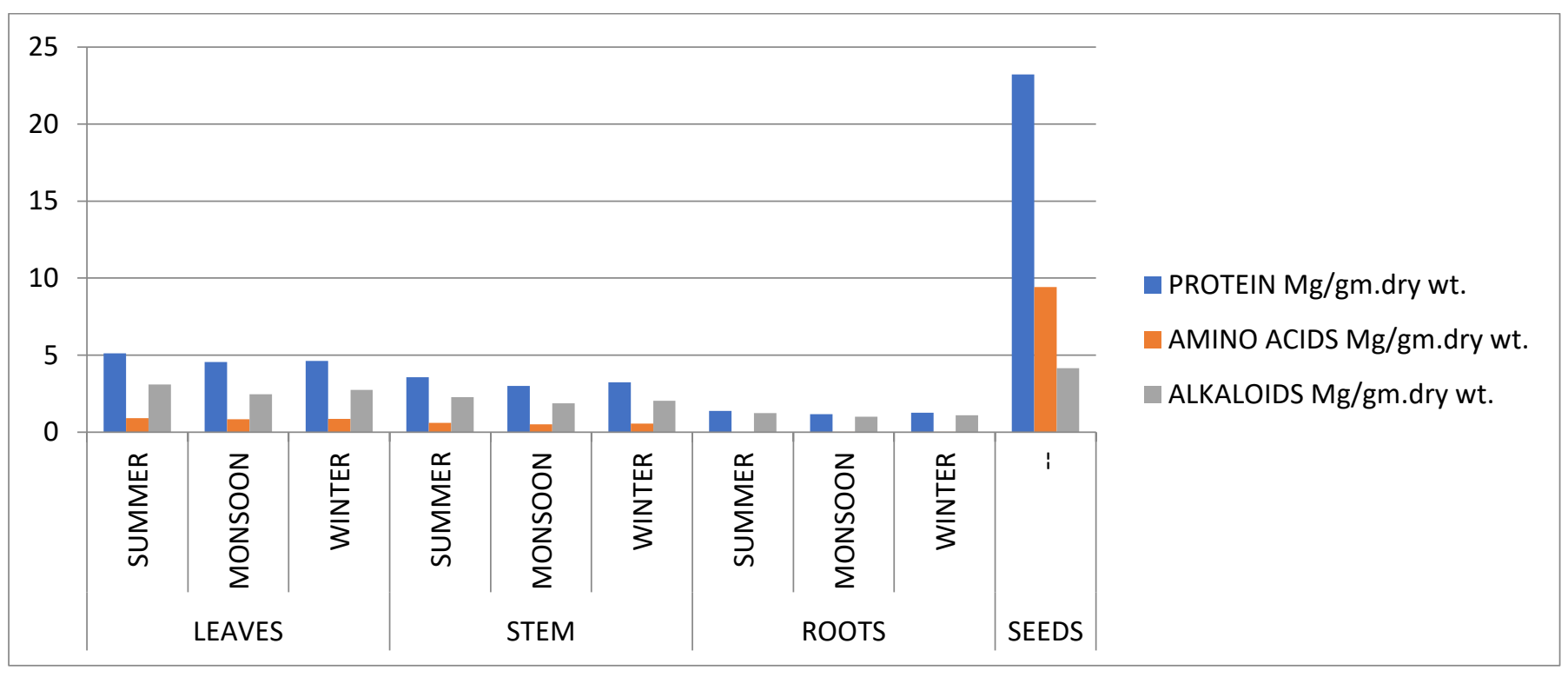

Figure 1: Seasonal variations of protein, amino acids and alkaloids of various parts of Trigonella foenum-graecum.

\section{References}

1. Jigna P, Sumitra C. Antibacterial and phytochemical studies on twelve species of Indian medicinal plants. African J Biomed Res 2007; 10: 175-181.

2. Yusuf AZ, Zakir A, Shemau Z, et al. Phytochemical analysis of the methanol leaves extract of Paullinia pinnata Linn. J Pharmacognosy Phytother 2014; 6: $10-16$.

3. Giri KR, Bibek GC, Kharel D, et al. Screening of phytochemicals, antioxidant and silver nanoparticles biosynthesizing capacities of some medicinal plants of Nepal. J Plant Sci 2: 77-81.

4. Tasneef A, Bahadur SS, Shivshankar P. "Phytochemical screening and physicochemical parameters of crud drugs: A brief review". Int $\mathrm{J}$ Pharma Res Rev 2013; 2: 53-60.

5. Indrayan AK, Sharma S, Durgapal $\mathrm{D}$, et al. "Determination of nutritive value and analysis of mineral elements for some medicinally valued plants from Uttaranchal". Current Sci 2005; 89: 1252-1255.

6. Raju J, Gupta D, Rao AR, et al. TSP Trigonella foenum graecum (Fenugreek) seed powder improves glucose homeostasis in alloxan diabetic rat tissues by reversing the altered glycolytic, gluconeogenic and lipogenic enzymes. Mol Cell Biochem 2001; 224: 45-51.

7. Srinivasan K. Fenugreek (Trigonella foenumgraecum): A review of heal beneficial physiological effects. Food Rev Int 2006; 22: 203224.

8. Khalki L, M'hamed SB, Bennis M, et al. Evaluation of the developmental toxicity of the aqueous extract from Trigonella foenum-graecum (L.) in Mice. J Ethnophar-macol 2010; 15: 321-325. 
9. Grover JK, Yadav S, Vats V. "Medicinal plants of India with anti-diabetic potential". J Ethnopharmacol 2002; 81: 81-100.

10. Allen O, Allen N. The Leguminosae; A source book of characteristic uses and Nodulation. Macmillan 1981.

11. Lowrey $\mathrm{OH}$, Rosenbrough NJ, Farr AL, et al. Protein measurement with the folin-phenol reagent. J Bio Chem 1951; 193: 265-275.
12. Krishnamurthy R, Bhagwat M. Testing salt tolerant variability in the nutritional quality of seeds produced by rice cultivars subjected to salinity. Seed Sci Technol 1989; 17: 269-275.

13. Sairam TV, Khanna P. Effect of tyrosine and phenylalanine on growth and production on alkaloids in datura tubula tissue culture. Lloydia 1971; 34.

This manuscript was peer-reviewed

Mode of Review: Single-blinded

Academic Editor: Dr. Bijay Kumar Mohanty

Copyright: (92018 Kadam VB. This article is distributed under the terms of the Creative Commons Attribution 4.0 International License (http://creativecommons.org/licenses/by/4.0/), which permits unrestricted use, distribution, and reproduction in any medium, provided you give appropriate credit to the original author(s) and the source, provide a link to the Creative Commons license, and indicate if changes were made. 